\title{
New faunistic records of spiders from East Kazakhstan (Arachnida: Aranei)
}

\section{Новые фаунистические находки пауков в восточном Казахстане (Arachnida: Aranei)}

\author{
Yuri M. Marusil** \& Dmitri V. Logunov** \\ Ю.М. Марусик*, А.В. Аогунов**
}

\author{
*Institute for Biological Problems of the North FEB RAS, Portovaya Str. 18, Magadan 68500, Russia. E-mail: yurmar@mail.ru \\ *Институт биологических проблем Севера ДВО РАН, ул. Портовая 18, Магадан 685000, Россия. \\ ** The Manchester Museum, The University of Manchester, Oxford Road, Manchester M13 9PL, UK. E-mail: \\ dmitri.v.logunov@manchester.ac.uk \\ ** Манчестерский Музей, Университет Манчестера, Оксфорд Роуд, Манчестер M13 9PL, Великобритания.
}

KEY WORDS: East Kazakhstan, spiders, Aranei, new findings, new species, revalidation.

КЛЮЧЕВЫЕ СЛОВА: Восточный Казахстан, пауки, Aranei, новые находки, новый вид, ревалидизация.

ABSTRACT. A list of 44 spider species collected from east Kazakhstan. A new species Acantholycosa tarbagataica sp.n. $\left(\mathrm{O}^{7}+\right)$ is described from the Tarbagatai Mt. Range. The species name Drassodes chybyndensis Esyunin et Tuneva, 2002 is removed from the synonymy with $D$. lacertosus (O. Pickard-Cambridge, 1872). Five species are recorded new to Kazakhstan: Drassodes chybyndensis Esyunin et Tuneva, 2002, Haplodrassus kulczynskii Lohmander, 1842; Zelotes gallicus Simon, 1814; Alopecosa accentuata (Latreille, 1817); and A. cinnameopilosa (Schenkel, 1963).

РЕЗЮМЕ. Приведён список 44 видов пауков, собранных в восточном Казахстане. Новый вид Acantholycosa tarbagataica sp.n. ( $\left.{ }^{7}+\right)$ описан c хребта Тарбагатай. Видовое название Drassodes chybyndensis Esyunin et Tuneva, 2002 восстановлено из синонимии с D. lacertosus (O. Pickard-Cambridge, 1872). Пять видов впервые отмечены для фауны Казахстана: Drassodes chybyndensis Esyunin et Tuneva, 2002, Haplodrassus kulczynskii Lohmander, 1842; Zelotes gallicus Simon, 1814; Alopecosa accentuata (Latreille, 1817); и A. cinnameopilosa (Schenkel, 1963).

\section{Introduction}

The spiders of east Kazakhstan remain incompletely studied. Besides the earlier works by Savelyeva [1970, 1972a,b,c, 1979], the only more or less comprehensive list of east Kazakhstan spiders (all families) exists for the Saur Mt. range [Eskov \& Marusik, 1995], presenting 199 species of which 19 were described as new. Apparently the best studied group of spiders of East Kazakhstan Region is the Salticidae, numbering 77 valid species [Logunov \& Marusik, 2000]. There is also a good deal of data for the east Kazakhstan Gnaphosidae [Tuneva, 2004; present data], with 26 species reported from the area.

The spiders reported on in this paper were collected by the second author (DL) during his fieldtrip to east Kazakhstan in May 2007. The details of all localities visited and habitats explored are given below. In the following list of species, each species name is followed by a number/letter in square brackets corresponding to the locality/habitat in which it was collected. The species recorded from Kazakhstan for the first time are marked with asterisks $(*)$.

Specimens were photographed using an Olympus Camedia E-520 camera attached to an Olympus SZX16 stereomicroscope. The images were montaged using "CombineZP" image stacking software. Photographs were taken in dishes of different sizes with paraffin wax at their bottom. Different sized holes were made in the bottom to keep the specimens in the correct position. Figures 27-29 were made by Sergei Zonstein (Department of Zoology, The George S. Wise Faculty of Life Sciences, Tel-Aviv University, Israel).

The format of description follows Marusik et al. [2003], all measurements are given in mm: male (female).

The following list (in total, 44 species) includes only the species determined for certain. The following six species have not been identified and therefore not included in the list: Cheiracanthidae (Cheiracanthium cf. pennyi/elegans: $2 \bigcirc^{\top} \sigma^{\top}-[2]$; C. cf. virescens: $1 \bigcirc^{7}-[4]$ ); Linyphiidae (Agyneta sp.: 2 o+ — [4]; Gen. sp.: 1 + [6]; Minyrioloides sp.: 3 ㅇ $-[1])$; Lycosidae (Trochosa sp.: 1 + - [4]).

The studied specimens have been shared between the following museums: MMUM - Manchester Mu- 


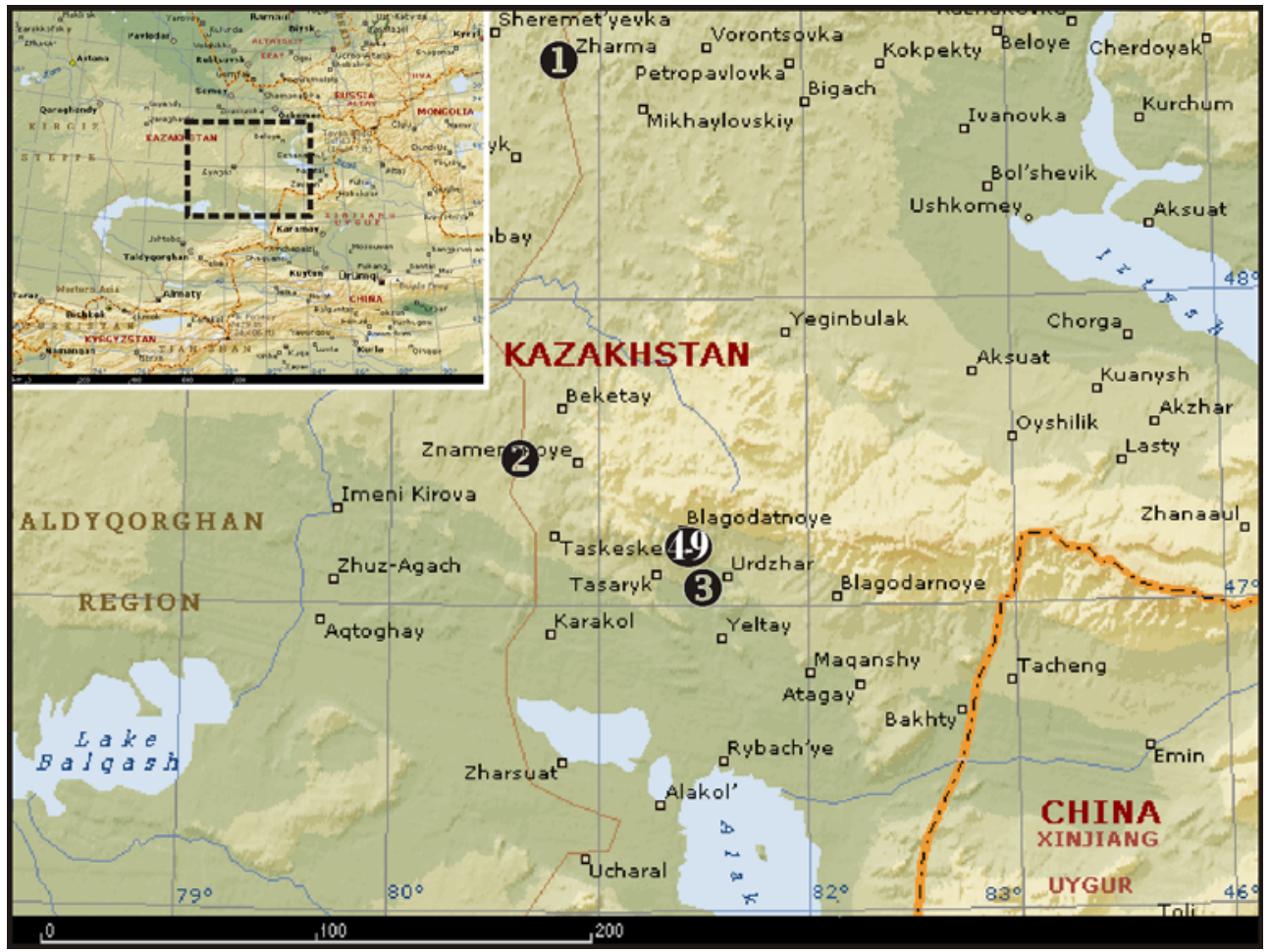

Map 1. Collecting localities in East Kazakhstan Region (Kazakhstan).

Карта 1. Точки сбора в Восточно-Казахстанской области (Казахстан).

seum of the University of Manchester, Manchester, UK, Dr D.V. Logunov; ZMUT - Zoological Museum of the Turku University, Turku, Finland, Dr S. Koponen.

Localities:

1. Kazakhstan, East Kazakhstan Region, Kara-Khol' Lake $\left(48.73^{\circ} \mathrm{N}, 80.82^{\circ} \mathrm{E}\right), 778 \mathrm{~m}$ a.s.1, in reeds, 17.05 . 2007. D.V. Logunov.

2. Kazakhstan, East Kazakhstan Region $\left(47.55^{\circ} \mathrm{N}\right.$, $\left.80.64^{\circ} \mathrm{E}\right), 715 \mathrm{~m}$ a.s.l, steppe, 18.05.2007. D.V. Logunov.

3. Kazakhstan, East Kazakhstan Region, nr. Ukzhar $\left(47.08^{\circ} \mathrm{N}, 81.60^{\circ} \mathrm{E}\right), 450 \mathrm{~m}$ a.s.1., on yarrow, 18.05 2007. D.V. Logunov.

4. Kazakhstan, East Kazakhstan Region, SW part of Tarbagatai Mt. Range $\left(47.14^{\circ} \mathrm{N}, 81.43^{\circ} \mathrm{E}\right), 1000$ $1200 \mathrm{~m}$ a.s.l., wild rose (Rosa sp.) and honeysuckle meadows, sweeping and hand collecting, 19-22.05. 2007. D.V. Logunov.

5. Ditto, pitfall traps.

6. Ditto, poplar grove in creek valley, sieving the litter and pitfall traps.

7. Kazakhstan, East Kazakhstan Region, SW part of Tarbagatai Mt. Range $\left(47.14^{\circ} \mathrm{N}, 81.43^{\circ} \mathrm{E}\right), 1600$ $1700 \mathrm{~m}$ a.s.1., under stones, 20.05.2007. D.V. Logunov.

8. Kazakhstan, East Kazakhstan Region, SW part of Tarbagatai Mt. Range $\left(47.14^{\circ} \mathrm{N}, 81.43^{\circ} \mathrm{E}\right), 1500$ $1600 \mathrm{~m}$ a.s.1., scree, 20.05.2007. D.V. Logunov.

\section{Descriptions and taxonomic notes}

Acantholycosa tarbagataica sp.n.

Figs 1-6, 10-13, Map 1.

TYPES. The $\sigma^{7}$ holotype, 2 우 paratypes and 1 subadult $\sigma^{7}$ (MMUM) from Kazakhstan, East Kazakhstan Region, SW part of Tarbagatai Mt. Range $\left(47.14^{\circ} \mathrm{N}, 81.43^{\circ} \mathrm{E}\right), 1500-1600 \mathrm{~m}$ a.s.l., scree, 20.05.2007. D.V. Logunov.

ETYMOLOGY. The new species is named after its type locality, Tarbagatai Mt. Range in east Kazakhstan.

DIAGNOSIS. The new species is most similar to $A$. altaiensis Marusik, Azarkina et Koponen, 2003 (Figs 7-9, 14-18) known from the west Altai. Both species have similar conformations of the palps and epigynes, and the same leg spination. Males of the new species can be distinguished by the following characters: the absence of dorsal keel on the tegular apophysis (cf. Figs 10 and 14), the presence of the bifurcated and obtuse embolic tip (singular and sharpened in $\mathrm{A}$. altaiensis; cf. Figs 10-11 and 14-15), the shape of paleal apophysis (lamella like in new species, and hooked in A. altaiensis; cf. Figs 7, 14-15, 18) and shape of the terminal apophysis (thick in new species, and spine like in A. altaiensis cf. Figs 15, 18). Females of the new species have the wider apical pocket and the larger epigynal septum (cf. Figs 4-6 and 8-9). 

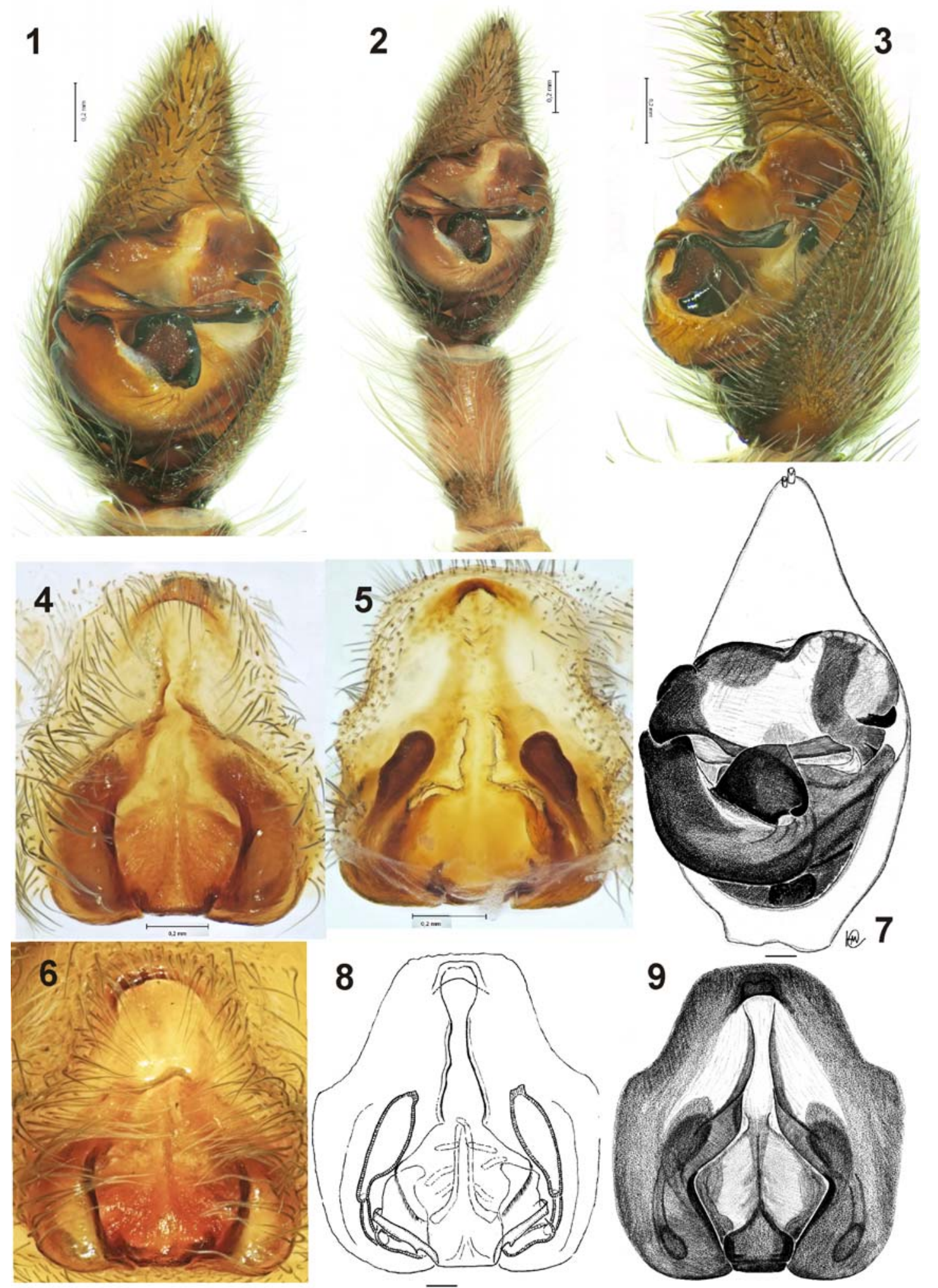

Figs 1-9. Copulatory organs of Acantholycosa tarbagataica sp.n. (1-6) and A. altaiensis (7-9): 1-2, 7 - male palp, ventral view; 3 - ditto, retrolateral view; 4, 6, 9 - epigyne, ventral view; 5, 8 - ditto, dorsal view. Figures 7-9 after Marusik et al. [2003]. Scale bars: $1-6=0.2 \mathrm{~mm}, 7-9=0.1 \mathrm{~mm}$.

Рис. 1-9. Копулятивные органы Acantholycosa tarbagataica sp.n. (1-6) и A. altaiensis (7-9): 1-2, 7 — пальпа самца, вентрально; 3 - тоже, ретролатерально; 4, 6, 9 - эпигина, вентрально; 5, 8 - тоже, дорзально. Рисунки 7-9 по Marusik et al. [2003]. Масштаб: $1-6=0,2$ мм, 7-9 = 0,1 мм. 

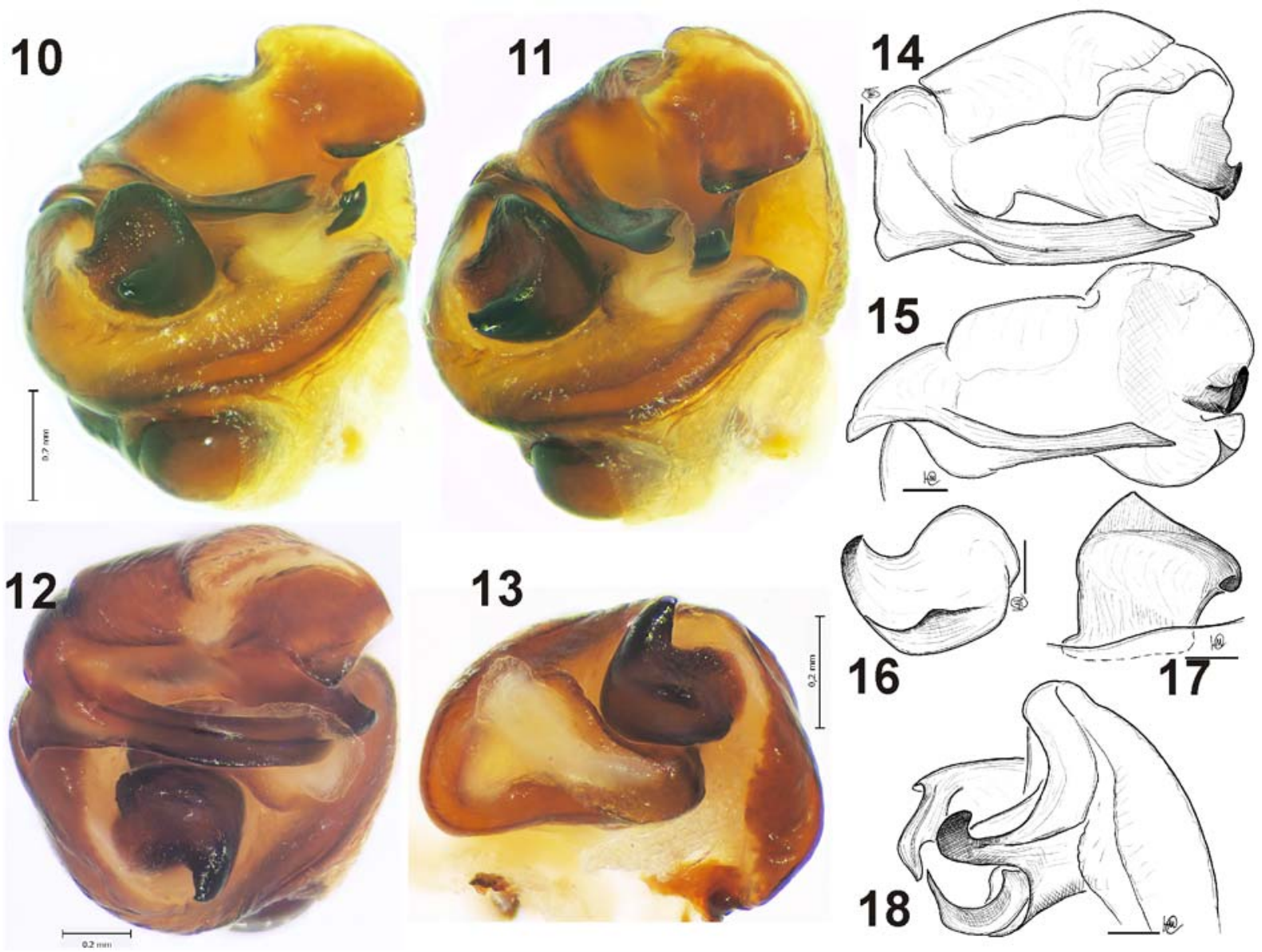

Figs 10-18. Male palps of Acantholycosa tarbagataica sp.n. (10-13) and A. altaiensis (14-18): 10-12 - bulbus, ventral, ventroretrolateral views and from above, respectively; 13 - tegulum, from above; $14-15,18$ - terminal part of bulbus, from above, ventral and retrolateral views, respectively; 16-17 - tegular apophysis, from above and ventral view, respectively. Figures 14-18 after Marusik et al. [2003]. Scale bars: $10-13=0.2 \mathrm{~mm}, 14-18=0.1 \mathrm{~mm}$.

Рис. 10-18. Пальпы самцов Acantholycosa tarbagataica sp.n. (10-13) и A. altaiensis (14-18): 10-12 - бульбус, вентрально, вентро-латерально и сверху; 13 - тегулум, сверху; 14-15, 18 - терминальная часть бульбуса, сверху, вентрально и ретролатерально; 16-17 - тегулярная апофиза, сверху и вентрально. Рисунки 14-18 по Marusik et al. [2003]. Масштаб: 10-13 = 0,2 мм, 14-18 = 0,1 MM.

COMMENTS. One female has one less pair of ventral tibial spines than in each of the two other specimens. This female has the slightly different epigyne (Fig. 6) with the wider apical pocket, the larger septum and undeveloped septal stem. Because all specimens were collected from the same scree we assume all of them are conspecific and therefore the deviating female is included in the type series.

DISTRIBUTION. The type locality only (Map 1).

DESCRIPTION. Total length 7.2(9.0). Carapace: 4.0 (4.7) long, 3.2(3.2) wide. Body coloration uniformly grayish or blackish, with no pattern. Carape/femur I ratio $0.97(1.04)$. Leg I segments: $4.1(4.5)+1.8(1.9)+$ $4.8(4.5)+4.4(4.0)+1.8(1.8)$. Three specimens $\left(\sigma^{7}\right.$ holotype, one $q$ paratype and immature $\sigma^{7}$ ) have the femur I with 2 pro- and 2 retrolateral spines, tibia I with 6 pairs of ventral spines, distal pair of spines smaller than the tibia diameter. One $q$ paratype has got 5 pairs of ventral tibial spines.
Male palp as shown in Figs 1-3, 10-13, cymbium with 2 claws, darker than other segments, the tegular apophysis without apical arm, the paleal apophysis lamellar, the terminal apophysis massive (not lamellar) with blunt tip; the embolic base with large "spine" in its basal part, the embolus wide, its tip split in two obtuse lobes.

Epigyne and spermathecae as shown in Figs 4-6, the epigynal pocket wide and undivided, the septal stem present (Figs 4-5) or absent (Fig. 6); the septum occupies the entire (Fig. 6) or almost entire epigynal depression.

Drassodes chybyndensis Esyunin et Tuneva, 2002 Figs 19-26.

D. chybyndensis Esyunin et Tuneva, 2002: 169, figs 1-7 ( $0^{\text {T }}+$; the type series is not examined).

MATERIAL. KAZAKHSTAN: $2 \sigma^{\top} \sigma^{\top} 1$ ( 9 (MMUM), East Kazakhstan Region, SW part of Tarbagatai Mt. Range $\left(47.14^{\circ} \mathrm{N}\right.$, 
$81.43^{\circ} \mathrm{E}$ ), $1000-1200 \mathrm{~m}$ a.s.l., wild rose (Rosa sp.) and honeysuckle meadows, sweeping and hand collecting, 19-22.05.2007. D.V. Logunov.

COMPARATIVE MATERIAL. One male and one female from the G. Levy's spider collection has been examined by the first author (YM) and then and photographed by Sergei Zonstein (Tel-Aviv University, Israel), but label data were not extracted.

COMMENTS. D. chybyndensis was described from Orenburg area of Russia, but later it was synonymised with D. lacertosus (O. Pickard-Cambridge, 1872) known from Syria, Israel and Turkey [see Levy, 2004]. A side by side comparison of the specimens from Israel, Kazakhstan and the type locality of $D$. chybyndensis has revealed that both species are distinct and the name D. chybyndensis should be revalidated. D. chybyndensis differs from $D$. lacertosus in having the entirely different epigyne (cf. Figs 25-26 and 29), not swollen palpal femur and longer palpal tibia (cf. Figs 22 and 28 ), the larger tegular apophysis, different course of the seminal duct and the longer embolus (cf. Figs 19 and 27).

DISTRIBUTION. The species is distributed from Orenburg Region of Russia [Esyunin \& Tuneva, 2002] to east Kazakhstan [present data].

\section{List of species}

\section{AGELENIDAE (2)}

Agelena labyrinthica (Clerck, 1757): 1 juv. - [6]. Paracoelotes birulai (Ermolaev, 1927): 1 ㄴ [8]. COMMENTS. This species name is currently considered a junior synonym of $P$. luctuosus (L. Koch, 1878) and assigned to Pireneitega Kishida, 1955 [Platnick, 2011]. We disagree both with the species synonymy and with the revalidation of Pireneitega, which was done against the principle of taxonomic stability. Since its original description, the name of Pireneitega has not been used for over 52 years, whereas Paracoelotes has been cited in several dozens of taxonomic papers.

\section{ARANEIDAE (3)}

Larinioides patagiatus (Clerck, 1757): 1 ○ - [4]. Larinioides suspicax (O. Pickard-Cambridge, 1876): $2 \sigma^{\top} \sigma^{\top} 1$ \% - [1]. [1].

Singa hamata (Clerck, 1757): $2 \sigma^{\top} \sigma^{\top} 2$ + 2 juv. -

\section{CLUBIONIDAE (1)}

Clubiona pallidula (Clerck, 1757): $10^{7}-[4]$.

\section{CORINNIDAE (1)}

Phrurolithus festivus (C.L. Koch, 1835): $2 \sigma^{\top} \sigma^{\top} 3$ oๆ 1 juv. - [6].

\section{DICTYNIDAE (3)}

Dictyna arundinacea (Linnaeus, 1758): $2 \sigma^{7} \sigma^{7} 1$ ㅇ - [4], $1 \sigma^{7}-[7]$.

Dictyna pusilla Thorell, 1856: $1 \bigcirc^{\top}-[1]$.

Dictyna uncinata Thorell, 1856: $1 \sigma^{\top}-[5]$.

\section{GNAPHOSIDAE (6)}

*Drassodes chybyndensis Esyunin et Tuneva, 2002: 2 $\sigma^{\top} \sigma^{\top} 1$ - — [4]. COMMENTS. See above (Figs 19-26).

Gnaphosa taurica Thorell, 1875: 1 ○ 9 우 — [4], 3 o + - [7].

*Haplodrassus kulczynskii Lohmander, 1842: $10^{7}$ - [6]. COMMENTS. This species has the trans-Palaearctic disjunctive range. Early it was known from $\mathrm{Eu}-$ rope (east of the Urals) and from the Russian Far East, Korea and NE China. It is the first record of the species from Central Asia. [6].

Micaria pulicaria (Sundevall, 1831): $1 \bigcirc^{7} 1$ juv. -

Poecilochroa variana (C.L. Koch, 1839): $2 \sigma^{7} \sigma^{7} 1$ + $-[4], 1$ - $-[7], 2$ juv. - [8].

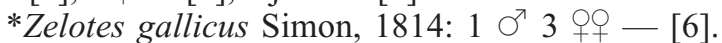
COMMENTS. Earlier this species was known west of the Urals only. The present record is the first for Kazakhstan, representing the south-easternmost locality of the species range.

\section{LINYPHIIDAE (2)}

Maso sundevalli (Westring, 1851): $1 \sigma^{7}-[6]$.

Pocadicnemis pumila (Blackwall, 1841): $3 \sigma^{7} \sigma^{7} 1$ †- [6].

\section{LIOCRANIDAE (1)}

Agroeca lusatica (L. Koch, 1875): 1 ○ - [5].

\section{LYCOSIDAE (6)}

Acantholycosa tarbagataica sp.n.: 1 ○ 2 우 [8], see above.

*Alopecosa accentuata (Latreille, 1817): $1 \sigma^{\top}-$ [5], $1 \sigma^{7}-$ [6]. COMMENTS. It is a new record for the fauna of Kazakhstan. This species is thought to have a trans-Palaearctic range [cf. Mikhailov, 1997 and Platnick, 2011], but we do not know any of the well documented records of $A$. accentuata from Siberia or from the Far East. Thus the species seems to be distributed from Europe to East Kazakhstan Area only.

*Alopecosa cinnameopilosa (Schenkel, 1963): 2 oq - [4]. COMMENTS. It is the first record of the species from Kazakhstan and the westernmost locality of its range. Earlier, this species was known from Japan to NW China (Xinjiang) [Song et al., 1999].

Alopecosa pulverulenta (Clerck, 1757): $2 \bigcirc^{7} \sigma^{7}-$ [5], 1 q - [6], 1 ○ 2 ơ - [7]. COMMENTS. 


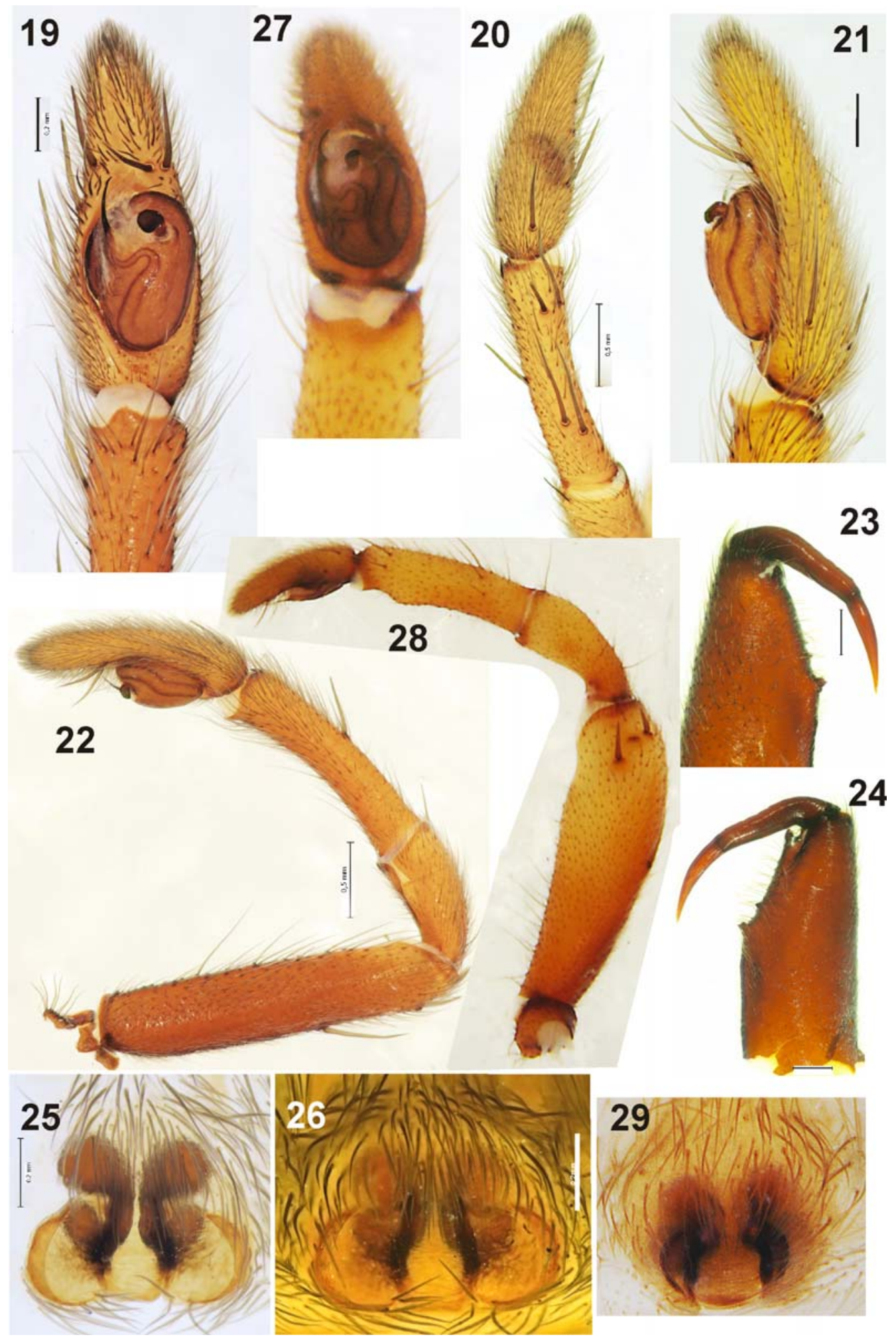

Figs 19-26. Drassodes chybyndensis (19-26) and D. lacertosus (27-29): 19, 27 - male palp, ventral view; 20-21 - ditto, dorsoprolateral and retrolateral view; 22, 28 - entire male palp, retrolateral view; 23-24 - male chelicera, frontal and inner views; 25-26, 29 - epigyne, ventral view; 25 - epigyne after maceration, ventral view. Scale bars: 19, 21, 25-26 = $0.2 \mathrm{~mm}, 20,22-24=0.5 \mathrm{~mm}$.

Рис. 19-26. Drassodes chybyndensis (19-26) и D. lacertosus (27-29): 19, 27 - пальпа самца, вентрально; 20-21 — тоже, дорзолатерально и ретро-латерально; 22,28 - целая пальпа самца, ретролатерально; $23-24$ - хелицера самца, фронтально и изнутри; 25-26, 29 - эпигина, вентрально; 25 - эпигина после мацерации, вентрально. Масштаб: 19, 21, 25-26 = 0,2 мм, 20, 22-24 = 0,5 мм. 
Specimens from east Kazakhstan are slightly smaller than those from Finland and their palps are slightly smaller as well.

Pardosa lugubris (Walckenaer, 1802): 1 \% - [4], 6

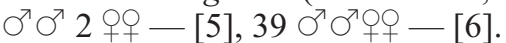
[6].

Pirata hygrophilus Thorell, 1872: $38 \sigma^{\top} \sigma^{7}+0$

\section{PHILODROMIDAE (1)}

Thanatus coloradensis Keyserling, 1880: $1 \bigcirc^{7} 19$ $-[4]$.

\section{SALTICIDAE (8)}

Aelurillus v-insignitus (Clerck, 1757): $2 \sigma^{7} \sigma^{\top} 4$ 우 $-[4]$. [4].

Evarcha arcuata (Clerck, 1757): 1 ㄴ [3], $1 \bigcirc^{\top}-$

Evarcha michailovi Logunov, 1992: $2 \sigma^{7} \sigma^{7}-[4]$ [4].

Euophrys frontalis (Walckenaer, 1802): $2 \bigcirc^{7} \sigma^{7}$

Heliophanus flavipes (Hahn, 1832): $1 \bigcirc^{7}-[4], 19$ - [6].

Heliophanus patagiatus Thorell, 1875: $1 \sigma^{7}-[7]$, $4 \bigcirc^{7} \sigma^{7}-[8]$. [4]. [4].

Heliophanus potanini Schenkel, 1963: $1 \bigcirc^{\top} 1$ 드

Philaeus chrysops (Poda, 1761): $3 \bigcirc^{\top} \bigcirc^{\top} 3$ 우

\section{SPARASSIDAE (1)}

Micrommata virescens (Clerck, 1757): $2 \sigma^{7} \sigma^{7} 19$ $-[4]$.

\section{TETRAGNATHIDAE (1)}

Pachygnatha listeri Sundevall, 1830: $1 \sigma^{7}-[6]$.

THERIDIIDAE (4)

[6].

Euryopis flavomaculata (C.L. Koch, 1836): $1 \bigcirc^{7}$

Steatoda albomaculata (De Geer, 1778): 1 - [7].

Theridion cinereum Thorell, 1875: 1 ㄴ [4].

\section{THOMISIDAE (4)}

Misumena vatia (Clerck, 1757): $4 \bigcirc^{\top} \bigcirc^{\top} 19-[4]$. Ozyptila praticola (C. L. Koch, 1837): $1+-[6]$. Xysticus cristatus (Clerck, 1757): $1 \bigcirc^{\top}-[3], 2$

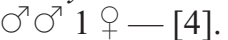

Xysticus dzhungaricus Tyshchenko, 1965: $1 \sigma^{7}$ [4], $1 \bigcirc^{7}-[6]$.
ACKNOWLEDGEMENTS. We are most grateful to Prof Victor V. Glupov (Novosibirsk, Russia) for inviting DL to the 2007 East Kazakhstan fieldtrip, in which the material treated in this paper was collected. We also thank Dr Sergei Zonstein (Tel-Aviv University, Israel) for taking photographs of D. lacertosus. Dr Jonathan Cooter (Oxford, UK) is thanked for his kind linguistic help. The research of the first author was supported by the Russian Foundation for Basic Research grants \#\# 09-04-01365 and 11-04-01716-a.

\section{References}

Eskov K.Yu., Marusik Yu.M. 1995. On the spiders from Saur Mt. range, eastern Kazakhstan (Arachnida: Araneae) // Beitr. Araneol. Bd.4. S.55-94.

Esyunin S.L., Tuneva T.K. 2002. A review of the family Gnaphosidae in the fauna of the Urals (Aranei), 1. Genera Drassodes Westring, 1851 and Sidydrassus gen.n. // Arthropoda Selecta. Vol.10. P.169-180.

Levy G. 2004. Spiders of the genera Drassodes and Haplodrassus (Araneae, Gnaphosidae) from Israel // Israel J. Zool. Vol.50. P.1-37.

Logunov D.V., Marusik Yu.M. 2000. Catalogue of the jumping spiders of northern Asia (Arachnida, Araneae, Salticidae). Moscow: KMK Scientific Press. 300 p.

Marusik Yu.M., Azarkina G.N., Koponen S. 2004. A survey of East Palaearctic Lycosidae (Aranei). II. Genus Acantholycosa Dahl, 1908 and related new genera // Arthropoda Selecta. Vol.12 (for 2003). No.2. P.101-148.

Mikhailov K.G. 1997. Catalogue of the spiders of the territories of the former Soviet Union (Arachnida, Aranei). Moscow: Zool. Museum, Moscow State Univ. 416 pp. [in Russian].

Platnick N. 2011. The World Spider Catalog, Version 11.5. American Museum of Natural History. Online at: http://research.amnh. org/entomology/spiders/catalog/INTRO1.html (accessed 12 March, 2011).

Savelyeva L.G. 1970. [The fauna and zoogeographical relations of spiders of the East Kazakhstan Area] // Biologiya i Geografiya. Vyp.6. P.78-88 [in Russian].

Savelyeva L.G. 1972a. [New species and subspecies of Clubionidae (Aranei) from East-Kazakhstan Area] // Zool. Zhurnal. Vol.51. Vyp.9. P.1404-1407 [in Russian].

Savelyeva L.G. 1972b. [New species of Gnaphosidae (Aranei) from East-Kazakhstan Area] // Zool. Zhurnal. Vol.51. Vyp.8. P.12381241 [in Russian, with English summary].

Savelyeva L.G. 1972c. [New and little known species of the spider family Lycosidae (Aranei) from East-Kazakhstan Area] // Entomol. Obozr. Vol.51. Vyp.2. P.454-462 [in Russian].

Savelyeva L.G. 1979. [Zoogeographical complexes of spiders (Aranei) from East Kazakhstan] // Priroda i khoz. Vost. Kazakhstana. Alam-Ata: Nauka. P.139-148 [in Russian].

Song D.X., Zhu M.S., Chen J. 1999. The Spiders of China. Hebei Sci. Technol. Publ. House, Shijiazhuang, 640 pp.

Tuneva T.K. 2004. A contribution on the gnaphosid spider fauna (Araneae: Gnaphosidae) of east Kazakhstan // Logunov D.V., Penney D. (eds.). European Arachnology 2003 (Proceedings of the 21st European Colloquium of Arachnology, St.-Petersburg, 4-9 August 2003). Arthropoda Selecta. Special Issue. No.1. P.319-332.

Responsible editor K.G. Mikhailov 